\title{
INDUSTRI 4.0: PENGARUH REVOLUSI INDUSTRI PADA KEWIRAUSAHAAN DEMI KEMANDIRIAN EKONOMI
}

\author{
Hamdan \\ Universitas Serang Raya \\ hamdanunsera@gmail.com
}



Jurnal Nusantara Aplikasi Manajemen Bisnis

http://ojs.unpkediri.ac.id/index.php/mana jemen/index

E-ISSN : 2528-0929
P-ISSN : $2549-5291$

Diterima: 5 Juni 2018

Revisi : 29 Juni 2018

Disetujui: 10 Oktober 2018

https:DOI 10.29407/nusamba.v3i2.12142

Abstract

The Industrial Revolution 4.0 is a new technological advancement that integrates the physical, digital and biological world, where there is a fundamental change in the human's way of life.

With the rapid development of technology that has experienced breakthroughs in all disciplines, including in the field of artifical intelligence, nanotechnology, biotechnology, internet-based technology has an impact on human life that can increase the economic growth too.

The impact of economic growth has increased in the 4.0 industrial revolution where this can be seen from many business people and entrepreneurs who utilize the information technology, so that the basic principles of industrial design 4.0 are known as the digital revolution because of the proliferation of computers and automation and connectivity in a field. With the Industrial Revolution 4.0, there is an increasing influence in the economic sector, where the sector opens opportunities for entrepreneurship and MSMEs increase rapidly, thus giving an impact on entrepreneurship for economic independence.

Keywords: Industrial Revolution 4.0, Entrepreneurship, Economic Independence, Computer Poliferation, Artificiall intellegent

Revolusi Industri 4.0 merupakan $\begin{aligned} & \text { Abstrak } \\ & \text { kemajuan teknologi baru yang }\end{aligned}$ mengintegrasikan dunia fisik, digital dan biologis, dimana terdapat perubahan cara hidup kerja manusia secara fundamental.

Dengan perkembangan teknologi yang semakin berkembang pesat yang mengalami terobosan semua disiplin ilmu, diantaranya dibidang artificiall intellegent, teknologi nano,bioteknologi, teknologi yang berbasis internet berdampak terhadap kehidupan manusia, sehingga memberikan dampak pertumbuhan ekonomi semakin meningkat.

Dampak dari pertumbuhan ekonomi semakin meningkat pada revolusi industri 4.0 dilihat banyak pelaku bisnis dan wirausaha memanfaatkan perkembangan teknologi informasi, sehingga prinsip-prinsip dasar desain industri 4.0 yang dikenal dengan revolusi digital karena terjadi proliferasi komputer dan otomatisasi dan konektivitas disebuah bidang. Dengan Revolusi Industri 4.0 memberikan pengaruh dibidang perekonomian meningkat, dimana sektor sektor membuka peluang untuk kewirausahaan dan UMKM meningkat dengan pesat, sehingga memberikan dampak pengaruh pada kewirausahaan demi kemandirian ekonomi.

Kata Kunci : Revolusi Industri 4.0, Kewirausahaan, Kemandirian Ekonomi, Poliferasi Komputer, Artificiall intellegent 


\section{JURNAL NUSAMBA VOL. 3 NO.2 Oktober $\mid \mathbf{2 0 1 8}$}

\section{Pendahuluan}

Revolusi industri merupakan perubahan cara hidup dan proses kerja manusia secara fundamental, dimana dengan kemajuan teknologi informasi dapat mengintregrasikan dalam dunia kehidupan dengan digital yang dapat memberikan dampak bagi seluruh disiplin ilmu. Dengan perkembangan teknologi informasi yang berkembang secara pesat mengalami terobosan diantaranya dibidang artificiall intellegent, dimana teknologi komputer suatu disiplin ilmu yang mengadopsi keahlian seseorang kedalam suatu aplikasi yang berbasis teknologi dan melahirkan teknolologi informasi dan proses produksi yang dikendalikan secara otomatis. Dengan lahirnya teknologi digital saat ini pada revolusi industri 4.0 berdampak terhadap kehidupan manusia diseluruh dunia. Revolusi industri 4.0 semua proses dilakukan secara sistem otomatisasi didalam semua proses aktivitasi, dimana perkembangan teknologi internet semakin berkembang tidak hanya menghubungkan manusia seluruh dunia namun juga menjadi suatu basis bagi proses transaksi perdagangan dan transportasi secara online.

Dengan perkembangan teknologi yang semakin berkembang banyak sekali munculnya bisnis transportasi online seperti Go-Jek ,Uber dan Grab dimana menunjukan integrasi aktivitas manusia dengan teknologi informasi, sehingga mengakibatkan pertumbuhan ekonomi semakin meningkat. Di Era revolusi industri 4.0 transportasi yang bersifat konvensional tidak pernah diprediksi bahwa model ini transportasi konvensional ini yang dahulu banyak digunakan oleh masyarakat untuk kepentingan mobilitas manusia, namun pada era revolusi industri 4.0 model transportasi konvensional ini sudah sedikit digunakan oleh masyarakat, dimana dapat terlihat antara taksi konvensional versi taksi online atau ojek pangkalan dengan ojek online, dengan perkembangan teknologi yang semakin berkembang secara pesat model transportasi konvensional model transportasi yang memanfaatkan dengan sistem aplikasi berbasis internet menjadi alat transportasi yang dimanfaatkan masyarakat untuk kepentingan mobilitas manusia, dampaknya publik menjadi lebih mudah mendapatkan layanan transportasi dan bahkan dengan harga yang sangat terjangkau. 


\section{JURNAL NUSAMBA VOL. 3 NO.2 Oktober $\mid \mathbf{2 0 1 8}$}



Gambar 1. Revolusi Industri 4.0 (Sumber: www.kompasiana.com)

Selain transportasi yang memanfaatkan teknologi informasi dengan memanfaatkan sistem aplikasi berbasis internet menjadi model transportasi yang dipilih oleh masyarakat, tidak sebatas sebagai transportasi online namun berkembang menjadi bisnis layanan (online delivery order), teknologi online yang telah membawa perubahan besar terhadap perubahan ekonomi. Di era revolusi industri 4.0 akan lebih cepat dalam perkembangan produk dan menciptakan konsumen yang beragam dan berdampak terhadap harga realatif murah, perubahan pada era ini tidak hanya pada perubahan cara atau strategi dalam proses pemasaran pada aspek fundamental.

Revolusi model bisnis di Era Industri 4.0 pertama, memberikan solusi terhadap permasalahan yang dihadapi masyakat, Kedua, pada era ini tidak pernah merasa puas dengan hasil yang dicapainya sehingga berupaya secara terus menerus melakukan inovasi. Ketiga model monopolistik kapitalisme baru, dimana model bisnis perusahaan perusahaan pada era ini menganut paham ekonomi berbagi (sharing ebonomy) sehingga dipersepsikan dapat menjadi solusi kesenjangan ekonomi. Keempat, model pemasaran 3.0, jika marketing pada era 1.0 fokus pada produk sedangkan di era 2.0 mareketing fokus kepada konsumen,maka pada marketing 3.0 lebih dari itu dimana perusahaan melihat konsumen tidak hanya sebatas pengguna produk tetapi melihat konsumen dari multi dimensinya sebagai manusia sehingga konsumen akan memilih produk yang memuaskan keinginannya untuk berpartisipasi, berkreasi,komunitas dan idealisme. 


\section{JURNAL NUSAMBA VOL. 3 NO.2 Oktober $\mid \mathbf{2 0 1 8}$}

\section{Tantangan dan Peluang Industri 4.0}

Perkembangan teknologi informasi dengan pesat saat ini terjadi otomotisasi yang terjadi diseluruh bidang, teknologi dan pendekatan baru yang menggabungkan secara nyata,digital dan secara fundamental (Tjandrawinata,2016). Beberapa tantangan yang dihadapi pada era industri 4.0yaitu masalah keamanan teknologi informasi, keandalan stabilitas mesin produksi, kurangnya keterampilan yang memadai,ketidakmampuan untuk berubah oleh pemangku kepentingan, dan hilangnya banyak pekerjaan karena berubah menjadi otomatisasi. Dengan hilangnya banyak pekerjaan karena berubah menjadi otomotisasi, sehingga pengangguran menjadi ancaman yang akan terjadi, dimana tingkat pengangguran pada bulan Februari 2017 sebesar 5,33\% atau 7,01 jiwa dari total 131,55 juta orang angkatan kerja (Sumber : BPPS 2017).

\section{Prinsip Desain Industri 4.0}

Beberapa prinsip desain industri 4.0 sebagai berikut, pertama, interkoneksi yaitu kemampuan mesin, perangkatsensor dan orang untuk terhubung dan berkomunikasi satu sama lain melalui internet of thing (IoT), prinsip ini membutuhkan kolaborasi keamanan dan standar. Kedua, transparansi informasi merupakan kemampuan sistem informasi untuk menciptakan salinan virtual dunia fisik dengan memperkaya model digital dengan data sensor termasuk data dan penyediaan informasi. Ketiga, bantuan teknis yang meliputi kemampuan sistem bantuan untuk mendukung manusia dengan menggabungkan dan mengevaluasi informasi secara sadar untuk membuat keputusan yang tepat dan memecahkan masalah mendesak dalam waktu singkat.Keempat, keputusan terdesentralisasi yang merupakan kemampuansistem fisik maya untuk membuat keputusan sendiri dan menjalankantugas seefektif mungkin. Secara sederhana, prinsip industri 4.0 menurutHermann et al (2016) dapat digambarkan sebagai berikut.






\section{JURNAL NUSAMBA VOL. 3 NO.2 Oktober $\mid \mathbf{2 0 1 8}$}

Gambar 2. Prinsip Industri 4.0 (Sumber: Hermann et al, 2016)

Revolusi industri 4.0 dikenal dengan revolusi digital karena terjadi proliferasi komputer dan otomatisasi pencatatan disemua bidang, karena otomatisasi dan konektivitas disebuah bidang akan membuat perubahan secara signifikan di dunia industri dan persaingan kerja menjadi tidak linier.Salah satu karakteristik dari revolusi industri 4.0 menerapkan pengaplikasikan kecerdasan buatan atau artificiall intellegent (Tjandarawinata,2016)

\section{Bidang kewirausahaan demi kemandirian ekonomi.}

Bidang Ekonomi pada revolusi industri 4.0 saat ini sedang pada perubahan besar pada kemajuan teknologi memungkinkan otomatisasi hampir disemua bidang. Diantara tantangan yang sedang dihadapi pada saat ini, teknologi yang menggabungkan dunia fisik,digital dengan cara yang fundamental mengubah umat manusia, sejauh mana transformasi ini akan berdampak positif.

Transformasi yang memberikan dampak positif, dimana peran dunia usaha dan organisasi sosial dinilai sangat strategis dalam memperkuat kemandirian ekonomi bangsa, sehingga pertumbuhan ekonomi mendorong pertumbuhan lebih kuat untuk mencapai pertumbuhan ekonomi 5\%.Meningkatnya kemandirian ekonomi mendorong dapat memperkuat orientasi kewirausahaan guna pertumbuhan lebih baik sehingga dapat mencapai tingkat kesejahteraan masyarakat secara merata.

Meningkatnya kemandirian ekonomi pada revolusi model bisnis di Era Industri 4.0terlihat pada model transportasi konvensional ini yang dahulu digunakan masyarakat untuk kepentingan mobilitas manusia, namun di Era revolusi industri 4.0 model transportasi konvensional ini tidak digunakan oleh masyarakat, model transportasi di era industri revolusi 4.0 Go-Jek dapat memberikan dampak positif dalam perekonomian Indonesia, karena dapat memberikan dampak sosial dan ekonomi secara langsung maupun tidak langsung yang dihasilkan oleh Go-Jek pada perekonomian Indonesia, Go-Jek memberikan dampak pada bidang perekonomian nasional dan masyarakat, Mitra Pengemudi, mitra UMKM dan dari pihak konsumen.Go-Jek memiliki kontribusi dalam perekonomian nasional dan masyarakat melalui penghasilan mitra pengemudi sekitar 8,2 triliun per tahun, sedangkan Go-Jek melalui penghasilan mitra UMKM memberikan kontribusi mencapai 1,7 triliun. (I Dewa G.K Wisana,dkk). Manfaat Go-Jek dapat kita rasakan dari sisi mitra pengemudi,dimana Go-Jek 


\section{JURNAL NUSAMBA VOL. 3 NO.2 Oktober $\mid \mathbf{2 0 1 8}$}

dapat mengurangi pengangguran, sehingga dapat memperluas kesempatan kerja, selain itu dapat meningkatkan penghasilan sehingga dapat meningkatkan kesejahteraan keluarga dan kualitas kehidupan keluarga pengemudi dapat meningkat. Selain itu peran GO-Jek dapat mendukung UMKM, dimana dengan Go-Jek dapat mendukung UMKM go online, sehingga dapat meningkatkan volume transaksi penjualan mitra UMKM, Go-Jek pun dapat membuka akses pasar untuk mendorong penggunaan perkembangan teknologi,sehingga dapat meningkatkan usaha.Selain itu Go-Jek dapat memberikan manfaat bagi konsumen, dampaknya masyarakat menjadi lebih mudah mendapatkan layanan transportasi dan bahkan dengan harga yang sangat terjangkau.

\section{Kesimpulan}

Revolusi Industri 4.0 dikembangkan dari revolusi 3.0, yang dimana revolusi 4.0 sering dikenal dengan Revolusi Digital, dimana ditandai poliferasi komputer dan otomatisasi pencatatan disemua bidang. Dengan perkembangan teknologi informasi yang mengalami terobosan diantaranya dibidang artificiall intellegent, teknologi nano, bioteknologi, teknologi komputer kuantum, teknologi berbasis internet. Dengan perkembangan ilmu pengetahuan dan teknologi yang semakin pesat telah melahirkan teknologi informasi dan proses produksi yang dikendalikan secara otomatis. Dengan lahirnya teknologi digital saat ini pada revolusi industri 4.0 berdampak terhadap kehidupan manusia di seluruh dunia. Beberapa prinsip desain industri 4.0 sebagai berikut, Pertama, interkoneksi yaitu kemampuan mesin, perangkat,sensor dan orang untuk terhubung dan berkomunikasi satu sama lain melalui internet of thing (IoT), prinsip ini membutuhkan kolaborasi keamanan dan standar. di Era revolusi industri 4.0 model transportasi konvensional kini beralih ke model transportasi yang memanfaatkan dengan sistem aplikasi berbasis internet menjadi alat trasportasi yang dimanfaatkan masyarakat untuk kepentingan mobilitas manusia, dampaknya publik menjadi lebih mudah mendapatkan layanan transportasi dan bahkan dengan harga yang sangat terjangkau. Selain itu dampak dari revolusi industri 4.0 sektor bidang perekonomian meningkat, dimana sektor sektor perdagangan dan UMKM meningkat dengan pesat. 


\section{DAFTAR PUSTAKA}

Aoun, J.E. (2017). Robot-proof: higher education in the age of artificialintelligence. US: MIT Press. Afwan, M. (2013). Leadership on technical and vocational education incommunity college [Versi elektronik]. Journal of Education andPractice, 4 (21), 21-23.

Baur, C. \& Wee, D. (2015). Manufacturing's Next Act? McKinsey \&Company.

Brofenbrenner, U. (1989). Ecological system theory. In r. Vasta (Ed).Annals of Child Development (Vol 6). Greenwich: CT, JAI Press.

Brown, A., Kirpal, S., \& Rauner, F. (2007). Identitas at work. Netherlands:Springer.

Bukit, M. (2014). Strategi dan inovasi pendidikan kejuruan darikompetensi ke kompetisi. Bandung: Alfabeta.

Cognizant. Informed Manufacturing: The Next Industrial Revolution. http://www.cognizant.com/InsightsWhitepapers/Informed-Manufacturing-TheNext-IndustrialRevolution.pdf.

Davis, N. 5 ways of understanding the Fourth Industrial Revolution. November 16, 2015. http://www.weforum.org/agenda/2015/11/5-ways-of-understanding-thefourth-industrialrevolution.

Economist Intelligence Unit. From transplants to implants. December 11, 2015. http://www.eiuperspectives.economist.com/healthcare/transplants-implants.

Edmon, A., \& Oluiyi, A. (2014). Re-engineering technical vocationaeducation and training toward safety practice skill needs ofsawmill workers against workplace hazards in Nigeria [Versielektronik]. Journal of Education and Practice, 5 (7), 150-157.

Era Revolusi Industri 4.0: Perlu Persiapkan Literasi Data, Teknologi dan Sumber Daya Manusia. (2018). Diambil 28 Maret 2018 dari http://belmawa.ristekdikti. go.id/2018/01/17/era-revolusiindustri-4-0-perlu-persiapkan-literasi-data-teknologi-dan-sumber-daya-manusia/

Fakta ketergantungan pada teknologi (2014). Diambil 27 Maret 2018 dari http://www.beritasatu.com/gaya-hidup/232713-8-fakta-ketergantungan-pada-teknologi.html

Hermann, M., Pentek, T., \& Otto, B. (2016). Design Principles forIndustrie 4.0 Scenarios. Presented at the 49th HawaiianInternational Conference on Systems Science.

Irianto, D. (2017). Industry 4.0; The Challenges of Tomorrow.Disampaikan pada Seminar Nasional Teknik Industri, Batu-Malang. Kagermann, H., Wahlster, W., \& Helbig, J.(2013). Recommendations forImplementing the Strategic Initiative Industrie 4.0. Industrie 4.0Working Group, Germany.

Inovasi disruptif.(2016). Diambil 27 Maret 2018 dari https://id.wiki-pedia.org/wiki/Inovasi_disruptif

Kennedy, O.O. (2011). Philosophical and sociological overview ofvocational-technical education in Nigeria [Versi elektronik].Journal of Academic Research in Business and Social Sciences, $1,167-175$.

Kuswana, W.S. (2013). Filsafat teknologi, vokasi dan kejuruan. Bandung:Alfabeta Bandung.

Kohler, D, \& Weisz, J.D. (2016). Industry 4.0: the challenges of thetransformingmanufacturing. Germany: BPIFrance.

Kompas. WEF: Tahun 2020, Lima Juta Pekerjaan Bisa Menghilang akibat Teknologi. Selasa, 19Januari2016.http://bisniskeuangan.kompas.com/read/2016/01/19/105938126/WEF.Tahun.2 020. Lima.Juta.Pekerjaan.Bisa.Menghilang.akibat.Teknologi.

Karnawati, D. (2017). Revolusi industri, 75\% jenis pekerjaan akan hilang. Diambil dari https://ekbis.sindonews.com/read/1183599/34/ revolusi-industri-75-jenis-pekerjaan-akanhilang-1488169341

Kasali, R. (2017). Meluruskan Pemahaman soal Disruption. Diambil dari https://ekonomi.kompas.com/read/2017/05/05/073000626/meluruskan.pemahaman.soal. disruption. 
Kompas. Penguasaan Teknologi Tentukan Indonesia. $22 \quad$ Januari 2016. http://print.kompas.com/baca/2016/01/22/Penguasaan-Teknologi-TentukanIndonesia.

Lee, J., Lapira, E., Bagheri, B., Kao, H., (2013). Recent Advances andTrends in Predictive Manufacturing Systems in Big DataEnvironment. Manuf. Lett. 1 (1), 38-41.

Liffler, M., \& Tschiesner, A. (2013). The Internet of Things and the Futureof Manufacturing. McKinsey \& Company.

Lomovtseva, N.V. (2014, Mei). Roles of VET in generating a newentrepreneur increative economy sector. Makalah disajikan dalam3rd International Conference on Vocational Education andTraining (ICVET), di Universitas Negeri Yogyakarta.

Murgor, T.K. (2013). Relationship Between Technical and VocationalAcquired Skills and Skills Required in Job Market: Evidence fromTVET institutions, Uasin Gishu County, Kenya [Versi elektronik].Journal of Education and Practice, 4 (19), 77-83.

Muhammad Yahya" era industri 4.0 : Tantangan dan Peluang perkembangan Pendidikan kejuruan Indonesia "Fakultas Teknik Universitas Negeri Makasae.

Pekerjaan yang diprediksi punah akibat revolusi industri apa saja. (2018). Diambil 28 Maret 2018 dari https://regional.kompas.com/ read/2018/01/31/17225241/pekerjaan-yang-diprediksi-punahakibat-revolusi-industri-apa-saja

Prosser, C.A., \& Quigley, T. (1950). Vocational Education in A Democrazy.Chicago USA: American Technical Society.

Peng, R., Lin, G., Li, J. Potential Pitfalls of CRISPR/Cas9-mediated Genome Editing. FEBS J. 2015 Nov 4. doi: 10.1111/febs.13586.

Robbins, R. The Fourth Industrial Revolution is Still About People and Trust. January 19, 2016. http://blogs.cisco.com/news/the-fourth-industrial-revolution-is-still-aboutpeople-and-trust.

Tjandrawina, R.R. (2016). Industri 4.0: Revolusi industri abad ini dan pengaruhnya pada bidang kesehatan dan bioteknologi. Jurnal Medicinus, Vol 29, Nomor 1, Edisi April.

Trilling, B \& Fadel, C. (2009). 21st-century skills: learning for life in ourtimes. US: Jossey-Bass A Wiley Imprint.

UBS. Extreme automation and connectivity: The global, regional, and investment implications of the $\begin{array}{llll}\text { Fourth Industrial } & \text { Revolution. }\end{array}$ https://www.staticubs.com/global/en/about_ubs/follow_ubs/highlights/davos2016/_jcr_conten t/par/columncontrol/col1/actionbutton.1402140804.file/bGluay9wYXRoPS9jb250ZW50L2Rh bS91YnMvZ2xvYmFsL2Fib3V0X3Vicy9mb2xsb3ctdWJzL3dl

Untung rugi revolusi industri 4.0 versi Presiden Jokowi. (2018). Diambil 25 Maret 2018 dari https://www.merdeka.com/uang/untung-rugi-revolusi-industri-40-versi-presiden-jokowi.html 